\title{
DESAIN PRIMER SPESIFIK UNTUK DETEKSI DINI PENYAKIT VIBRIOSIS PADA UDANG PENAEID
}

\author{
Ince Ayu Khairana Kadriah"), Endang Susianingsih"), Sukenda**), \\ Munti Yuhana ${ }^{* *}$, dan Enang Harris ${ }^{* *}$ \\ *) Balai Penelitian dan Pengembangan Budidaya Air Payau \\ Jl. Makmur Dg. Sitakka No. 129, Maros 90512, Sulawesi Selatan \\ E-mail:e_sisy@yahoo.com \\ **) Departemen Budidaya Perairan, Fakultas Perikanan dan Ilmu Kelautan, \\ Institut Pertanian Bogor \\ Jl. Rasamala, Kampus IPB Darmaga, Bogor 16680
}

(Naskah diterima: 13 Juli 2012; Disetujui publikasi: 28 Februari 2013)

\begin{abstract}
ABSTRAK
Serangan Vibriosis, yang disebabkan oleh Vibrio harveyi berpendar pada budidaya udang telah menyebabkan penurunan yang signifikan dalam produksi, baik pada pembenihan maupun di tambak pembesaran. Pengembangan metode deteksi cepat berbasis PCR (Polymerase Chain Reaction) sangat penting untuk mencegah penularan vibriosis. Tujuan dari penelitian ini adalah untuk mengembangkan metode cepat deteksi vibriosis pada udang penaeid dengan menggunakan penanda molekuler yang spesifik. PCR berbasis deteksi gen spesifik dilakukan menggunakan primer spesifik toxR, haemolysin (vvh), dan gyrB. Dari 35 isolat, 22 isolat yang terdeteksi memiliki gen spesifik toxR, haemolysin (vvh) dan gen gyrB dan 9 isolat terdeteksi memiliki dua gen tertentu. Penanda molekuler spesifik telah dirancang menggunakan data urutan gen penyandi protein haemolysin dan gyrase. Desain pasangan primer yang didasarkan pada program perangkat lunak dari Primer3 dan secara manual menggunakan program perangkat lunak Bioedit. Tiga pasangan primer untuk gen haemolysin dan dua primer gyrase telah diperoleh dan dipilih sebagai primer.
\end{abstract}

KATA KUNCl: vibriosis, udang penaeid, PCR, deteksi cepat, penanda molekuler spesifik

ABSTRACT: Specific primer design for rapid detection of Vibriosis on penaeid shrimp. By: Ince Ayu Khairana Kadriah, Endang Susianingsih, Sukenda, Munti Yuhana, and Enang Harris

Vibriosis occurrences, due to luminous Vibrio harveyi, on shrimp culture may caused substantial declines in production, either in hatcheries or in grow out ponds. Development of Polymerase Chain Reaction (PCR)-based rapid detection methods is very crucial in preventing vibriosis outbreaks. The aims of this study was to develop rapid methods of detection of the vibriosis in penaeid shrimp by using specific molecular markers. PCR-based detection of specific genes were performed employing specific primers of toxR, haemolysin (vvh) and gyrB. Out of the 35 isolates, 22 isolates were detected to have toxR, haemolysin $(v v h)$ and gyrB specific genes and 9 isolates have two out of these specific genes. Specific markers have been designed using sequence data of the genes encoding the haemolysin protein and gyrase. Primer pairs design were based on the software program of Primer 3 and manually aligned 
by using Bioedit software program. Three of primer pairs for haemolysin gene and two of gyrase primers were obtained and selected as primer.

\section{KEYWORDS: vibriosis, penaeid shrimp, PCR, rapid detection, specific molecular marker}

\section{PENDAHULUAN}

Kementerian Kelautan dan Perikanan masih menempatkan udang sebagai komoditas unggulan perikanan budidaya selama 20102014. Selama periode 2010-2014 produksi udang diharapkan meningkat $74,75 \%$ atau dari 400 ribu ton menjadi 699 ribu ton yang terdiri atas udang vaname dan udang windu. Industri budidaya udang windu secara intensif dan transportasi udang windu ke seluruh dunia melalui perdagangan diketahui berhubungan erat dengan meningkatnya kejadian infeksi penyakit yang menyerang udang windu selama dua dekade ini (Saulnier et al., 2000). Bakteri vibrio berpendar adalah salah satu penyebab penyakit yang cukup banyak menyerang hewan budidaya seperti udang (Baticados et al., 1990; Karunasagar et al., 1994; Moriarty, 1998; Zhang \& Austin, 2000), beberapa spesies ikan dan kekerangan (Austin \& Zhang, 2006) bahkan juga karang (BenHaim et al., 2003) di seluruh dunia.

Pengembangan metode deteksi cepat, tepat, akurat dan murah sangat bermanfaat karena dapat digunakan dalam upaya pencegahan penyakit vibriosis di lapangan baik di panti benih maupun pada pembesaran udang di tambak. Upaya pencegahan ini harus dilakukan sebelum koloni bakteri mencapai quorum. Penelitian yang dilakukan oleh Defoirdt (2007) menyimpulkan bahwa kemampuan bakteri vibrio untuk melakukan quorum sensing sangat dipengaruhi oleh populasi bakteri tersebut di alam. Upaya untuk deteksi cepat secara molekular salah satunya dengan mengisolasi gen spesifik yang dimiliki oleh bakteri vibrio berpendar dan digunakan sebagai penanda molekular dalam diagnosis cepat untuk penyakit vibriosis berpendar (kunang-kunang) pada budidaya udang.

Gen haemolysin diketahui merupakan gen spesifik yang dimiliki bakteri Vibrio berpendar. Gen haemolysin adalah gen yang bertanggung jawab pada penghancuran membran sel darah atau proses hemolisis. Gen yang mengkode haemolysin ini dilaporkan ditemukan pada beberapa spesies bakteri di antaranya adalah V. harveyi (Nishibuchi et al., 1990; Nishibuchi \& Kaper, 1995; Zhang et al., 2001) dan V. parahaemolyticus (Bej et al., 1999).

Selain gen haemolysin gen toxR yang secara spesifik mengkode protein transmembran juga memegang peranan penting pada regulasi gen toksin ctx dan beberapa gen-gen toksin lainnya. Gen toxR akan mengaktifkan gen-gen lainnya untuk menghasilkan toksin (Pang et al., 2006). Gen gyrB diketahui berperan untuk mengkode protein subunit $B$ dari DNA gyrase (topoisomerase type II). DNA gyrase mengatur superkoiling pita ganda DNA. Gen gyrB sangat diperlukan untuk replikasi DNA di mana gen ini berperan dalam pembentukan protein yang mengkode enzim gyrase.

Pendekatan yang memanfaatkan kemajuan bioinformatika dan teknik PCR dapat digunakan untuk mengembangkan penanda spesifik tersebut. Metode PCR digunakan untuk mengamplifikasi sekuen spesifik dari rantai DNA. Primer rantai pendek oligonukleotida yang didesain akan berkomplemen dengan masingmasing ujung dari daerah target pada rantai DNA dan kemudian memperpanjangnya pada sisi yang berlawanan dari DNA template. Karena fungsi primer sebagai inisiator sekaligus pembatas daerah yang akan diamplifikasi, maka idealnya primer memiliki urutan basa nukleotida yang tepat berpasangan dengan urutan basa DNA target yang akan diamplifikasi, dan tidak menempel di bagian lainnya. Desain primer yang bagus merupakan hal esensial bagi keberhasilan reaksi PCR.

Untuk mendesain suatu primer memerlukan data-data sekuen gen yang menyandikan protein sejenis dengan gen yang akan diamplifikasi melalui PCR. Data-data sekuen gen dapat diperoleh pada basis data gen dari lembaga-lembaga penyedia informasi gen dan protein atau hasil sekuen gen tertentu yang bersifat spesifik yang telah dihasilkan. Proses amplifikasi dari gen-gen yang mengkode sifatsifat tertentu utamanya sifat patogen dapat menjadi suatu pendekatan baru dalam metode deteksi cepat penyakit (Cunningham, 2002). 


\section{BAHAN DAN METODE}

Penelitian dilakukan di Laboratorium Kesehatan Ikan dan Lingkungan Balai Penelitian dan Pengembangan Perikanan Budidaya Air Payau, Maros. Analisis sekuensing dilaksanakan di Laboratorium Bioteknologi UNIKA Atmajaya, Jakarta dan Laboratorium $1^{\text {st }}$ Base Singapura. Tahapan Penelitian terdiri atas:

Isolasi Bakteri Vibrio Patogen dari Panti Benih dan Tambak Udang Windu

Sampel bakteri dan udang windu dikoleksi dari tambak percobaan Balai Penelitian dan Pengembangan Budidaya Air Payau, Maros di Maranak dan Takalar serta tambaktambak udang windu di Barru, Pangkep, Pinrang, Banyuwangi, dan Bali. Bakteri diisolasi dari air tambak, sedimen tambak, dan udang sakit. Sampel air diambil dengan menggunakan botol steril kemudian dibawa ke laboratorium. Sedangkan sampel sedimen diambil menggunakan sudip steril dan dibawa ke laboratorium menggunakan botol steril. Isolasi bakteri dilakukan dengan cara mengambil $1 \mathrm{~mL}$ air sampel dan $1 \mathrm{~g}$ sedimen tambak kemudian diencerkan secara bertingkat dalam larutan fisiologis (Benson, 1985) dan dikultur pada media TCBSA (Thiosulfate Citrate Bile Sucrose Agar). Bakteri juga diisolasi dari hepatopankreas udang windu.

\section{Deteksi Gen Spesifik pada Bakteri Vibrio Berpendar}

Pada penelitian ini digunakan primer spesifik untuk mendeteksi gen-gen spesifik toxR gene, haemolysin ( $v v h$ ) gene dan GyrB gene dengan metode PCR (Tabel 1). Primerprimer ini digunakan untuk mendeteksi gengen spesifik pada isolat bakteri yang diisolasi dari tambak dan panti benih di berbagai daerah di Sulawesi Selatan dan Jawa.

\section{Isolasi Genom Bakteri Kandidat}

Metode yang digunakan dalam isolasi genom bakteri adalah metode phenol-chloroform yang dikembangkan oleh Parenrengi (2000). Bakteri dikultur di dalam nutrient broth selama empat jam kemudian dipanen dengan cara sentrifugasi. Sebanyak $1 \mathrm{~mL}$ biakan bakteri dipindahkan ke dalam tabung eppendorf steril 1,5 mL dan disentrifugasi (6.000 rpm; 10 menit). Proses sentrifugasi diulang sebanyak dua kali dan kemudian dilakukan pencucian dengan larutan fisiologis juga dengan sentrifugasi.
Pelet bakteri yang dihasilkan kurang lebih $50 \mathrm{mg}$ kemudian dicampur dengan $500 \mu \mathrm{L}$ lysis buffer, $20 \mu \mathrm{L}$ proteinase-K (stok $20 \mathrm{mg} /$ $\mathrm{mL}$ ), dan $40 \mu \mathrm{L}$ sodium dodecyl sulfate (SDS) $10 \%$. Setelah itu, lisat bakteri diinkubasi dalam waterbath selama 1-3 jam pada suhu $55^{\circ} \mathrm{C}$. Penambahan 12,5 $\mu$ L RNAse dilakukan sebelum lisat disimpan pada suhu ruang selama 1530 menit. Selanjutnya ditambahkan Phenol: Chloroform:Isoamyl alcohol (PCIA 25:24:1) sebanyak $500 \mu \mathrm{L}$. Tabung eppendorf dihomogenkan dengan menggunakan mini mixer secara perlahan sampai homogen dan disimpan pada suhu ruang selama 10 menit. Selanjutnya disentrifugasi pada kecepatan $13.000 \mathrm{rpm}$ selama delapan menit. Lapisan paling atas diambil dan dipindahkan ke tabung eppendorf baru dan dilakukan penambahan PCIA seperti sebelumnya.

Setelah lapisan paling atas dipindahkan ke tabung eppendorf baru, kemudian dilakukan penambahan satu bagian larutan Chloroform: Isoamyl alcohol (CIA 24: 1) dan disentrifugasi selama empat menit dengan kecepatan 13.000 rpm. Lapisan paling atas dipindahkan ke tabung eppendorf baru. Kemudian ditambahkan dua bagian ethanol absolut dingin dan dicampur perlahan sampai homogen selanjutnya dilakukan sentrifugasi dengan kecepatan 6.000 rpm selama 30 menit. Cairan dibuang kemudian pelet DNA dicuci dengan $1 \mathrm{~mL}$ ethanol $70 \%$ kemudian disentrifugasi dengan kecepatan $6.000 \mathrm{rpm}$ selama 15 menit. Pellet DNA dikeringkan selama satu malam dan setelah kering ditambahkan $100 \mu \mathrm{L}$ Buffer TrisEtilendiamin Tetra Acetic Acid (EDTA) (TE) dan selanjutnya disimpan pada suhu $-20^{\circ} \mathrm{C}$ sampai digunakan (Parenrengi, 2000).

\section{Proses PCR}

Deteksi gen spesifik dilakukan dengan melakukan amplifikasi DNA menggunakan teknik Polymerase Chain Reaction (PCR). Proses PCR dilakukan menggunakan Kit PCR Ready To Go (RTG) dengan primer spesifik komersil yang sudah ada dan dilakukan optimasi pada beberapa tingkatan suhu annealing.

Proses ampifikasi DNA untuk primer toxR adalah sebagai berikut: larutan master mix dibuat dengan mencampur $20 \mu \mathrm{L}$ aquadest milliQ ke dalam 1 tube RTG (GE Healthcare UK Limited Little Chalfont Buckinghamshire, UK), kemudian ditambahkan masing-masing $1 \mu \mathrm{L}$ Primer toxRR1 dan toxRF1 (Pang et al., 2006). 


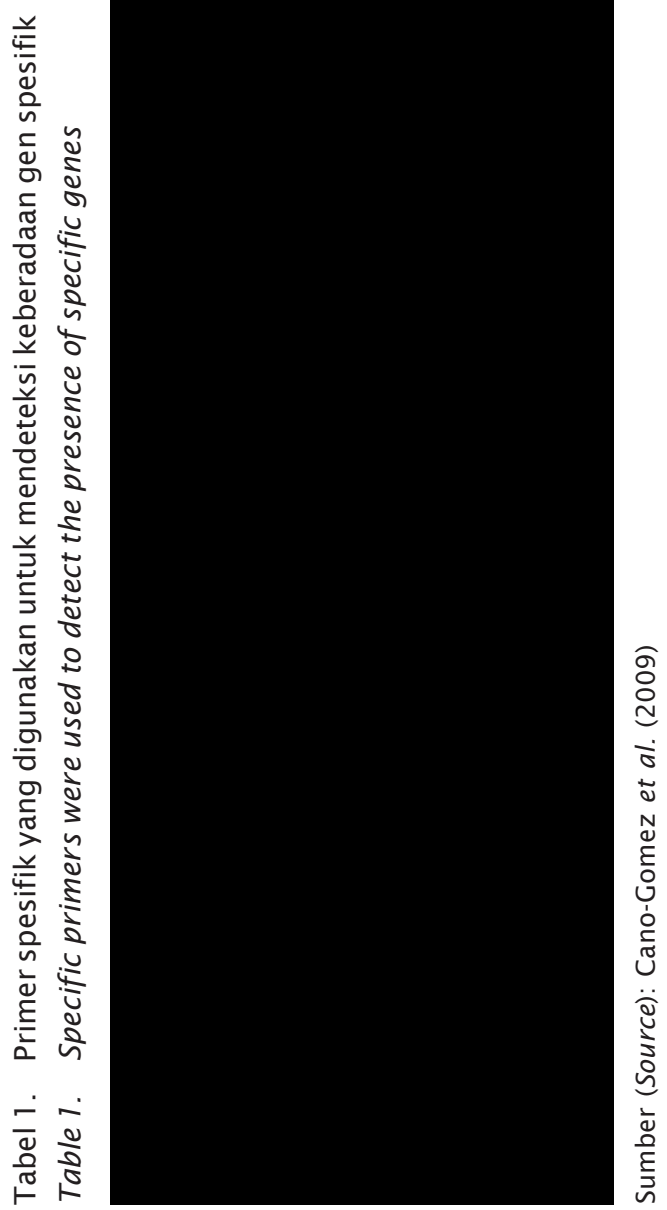


Setelah larutan dihomogenkan selanjutnya dimasukkan template DNA sebanyak $3 \mu \mathrm{L}$. Kondisi proses amplifikasi untuk primer spesifik toxR diatur sebanyak 30 siklus pada suhu denaturasi $94^{\circ} \mathrm{C}$ selama satu menit, annealing $57^{\circ} \mathrm{C}$ selama satu menit dan elongasi $72^{\circ} \mathrm{C}$ selama satu menit serta tahap ekstra elongasi $72^{\circ} \mathrm{C}$ selama sepuluh menit pada mesin PCR (Applied Biosystems 2720 Thermal Cycler). Proses amplifikasi DNA untuk primer spesifik vvhgen (haemolysin) diatur sebanyak 30 siklus pada suhu denaturasi $94^{\circ} \mathrm{C}$ selama satu menit, annealing $53^{\circ} \mathrm{C}$ selama satu menit dan elongasi $72^{\circ} \mathrm{C}$ selama satu menit (Conejero \& Hedreyda, 2004). Sedangkan untuk amplifikasi gen gyrB proses PCR juga diatur sebanyak 30 siklus dengan suhu denaturasi $94^{\circ} \mathrm{C}$ selama satu menit, annealing $60^{\circ} \mathrm{C}$ selama satu menit dan elongasi $72^{\circ} \mathrm{C}$ selama dua menit serta tahap ekstra elongasi $72^{\circ} \mathrm{C}$ selama tujuh menit (Thaithongnum et al., 2006).

\section{Elektroforesis}

Hasil PCR kemudian diaplikasikan pada gel agarosa $2 \%$ untuk diobservasi dan didokumentasikan. Elektroforesis minigel hanya optimum untuk pemisahan DNA berukuran kecil (ratusan bp hingga sekitar $10 \mathrm{~kb}$ ). Proses elektroforesis menggunakan minigel yang dialiri listrik dengan voltase $150 \mathrm{~V}$ dan kuat ampere 70 waktu running selama 30 menit. Larutan yang digunakan adalah buffer elektroforesis yang diperlukan untuk menciptakan kondisi stabil selama proses berlangsung. Pada umumnya bufferyang digunakan berupa Tris Aceticacid EDTA (TAE) atau Tris Boric EDTA (TBE). Untuk pewarna gel digunakan red gel sebagai pengganti etidhium bromide yang sudah tidak dianjurkan lagi karena bersifat karsinogenik.

\section{Desain Primer Spesifik}

Gen-gen spesifik yang sudah berhasil diamplifikasi dengan primer terpublikasi kemudian dianalisis urutan basa DNA-nya dengan metode sekuensing. Hasil sekuensing ini menjadi rujukan untuk mendesain primer spesifik. Setelah hasil sekuensing sudah diperoleh selanjutnya adalah mengumpulkan sekuen gen target sebagai referensi. Sekuen referensi dapat diperoleh dari database GenBank di situs NCBI (http://www.ncbi.nlm. nih.gov/). Sekuen referensi akan digunakan dalam uji BLAST (http://blast.ncbi.nlm. nih. gov/Blast) untuk mengetahui kemiripan sekuen gen yang dimiliki dengan sekuen dari gen sejenis yang sudah terdeposit pada NCBI. Urutan basa dari gen target dalam format notepad dapat langsung diunduh setelah laman NCBI/BLAST/blastn suite terbuka. Tahapan selanjutnya adalah menentukan perangkat lunak yang akan digunakan untuk desain primer. Pada dasarnya sembarang daerah tertentu pada sekuen referensi dapat diambil untuk dijadikan primer, tanpa perlu bantuan perangkat lunak khusus. Namun pada penelitian ini digunakan bantuan perangkat lunak Primer3 Plus (http://frodo.wi.mit.edu/ cgi-bin/primer3). Setelah software sudah berhasil diunduh, maka proses desain primer sudah dapat dimulai.

\section{HASIL DAN BAHASAN \\ Hasil Deteksi Gen-Gen Spesifik pada Vibrio Berpendar}

Dari 35 isolat yang diisolasi dari berbagai daerah, 22 isolat terdeteksi memiliki gen spesifik, di mana sembilan di antaranya terdeteksi memiliki dua gen spesifik (Tabel 2). Isolat bakteri yang memiliki gen spesifik ini kemudian diuji virulensinya dengan uji patogenisitas secara invivo menggunakan hewan uji udang windu. Isolat kode 1, 120, 170, dan 275 terbukti memiliki tingkat patogenisitas lebih tinggi dibandingkan isolat bakteri vibrio berpendar lainnya (Tabel 2). Isolat yang memiliki tingkat patogenisitas tinggi kemudian dipilih untuk dikarakterisasi gen spesifik haemolysin dan gyrase-nya dengan proses sekuensing. Untuk gen spesifik ToxR tidak dapat disekuensing disebabkan hasil PCR yang divisualisasikan pada gel elektroforesis menunjukkan adanya penempelan yang tidak spesifik dari primer (unspecific annealing) sehingga tidak terbentuk pita tunggal DNA.

Haemolysin adalah eksotoksin yang bertanggung jawab dalam proses penyerapan membran eritrosit atau proses hemolisis sel darah. Gen yang mengkode haemolysin ini dilaporkan ditemukan pada beberapa spesies bakteri yang termasuk genus vibrio (Conejero \& Hedreyda, 2004). Bakteri vibrio patogen yang memiliki gen haemolysin diketahui dapat menyebabkan terjadinya lysis pada sel darah inang.

Enzim gyrase terdistribusi hampir pada semua spesies dalam genus vibrio. Enzim ini yang mengurangi tekanan saat doublestranded DNA sedang tidak terikat oleh ikatan helikase hal ini menyebabkan terjadinya 
Tabel 2. Hasil deteksi gen-gen spesifik bakteri vibrio berpendar

Table 2. The results of the detection of specific genes luminous Vibrio

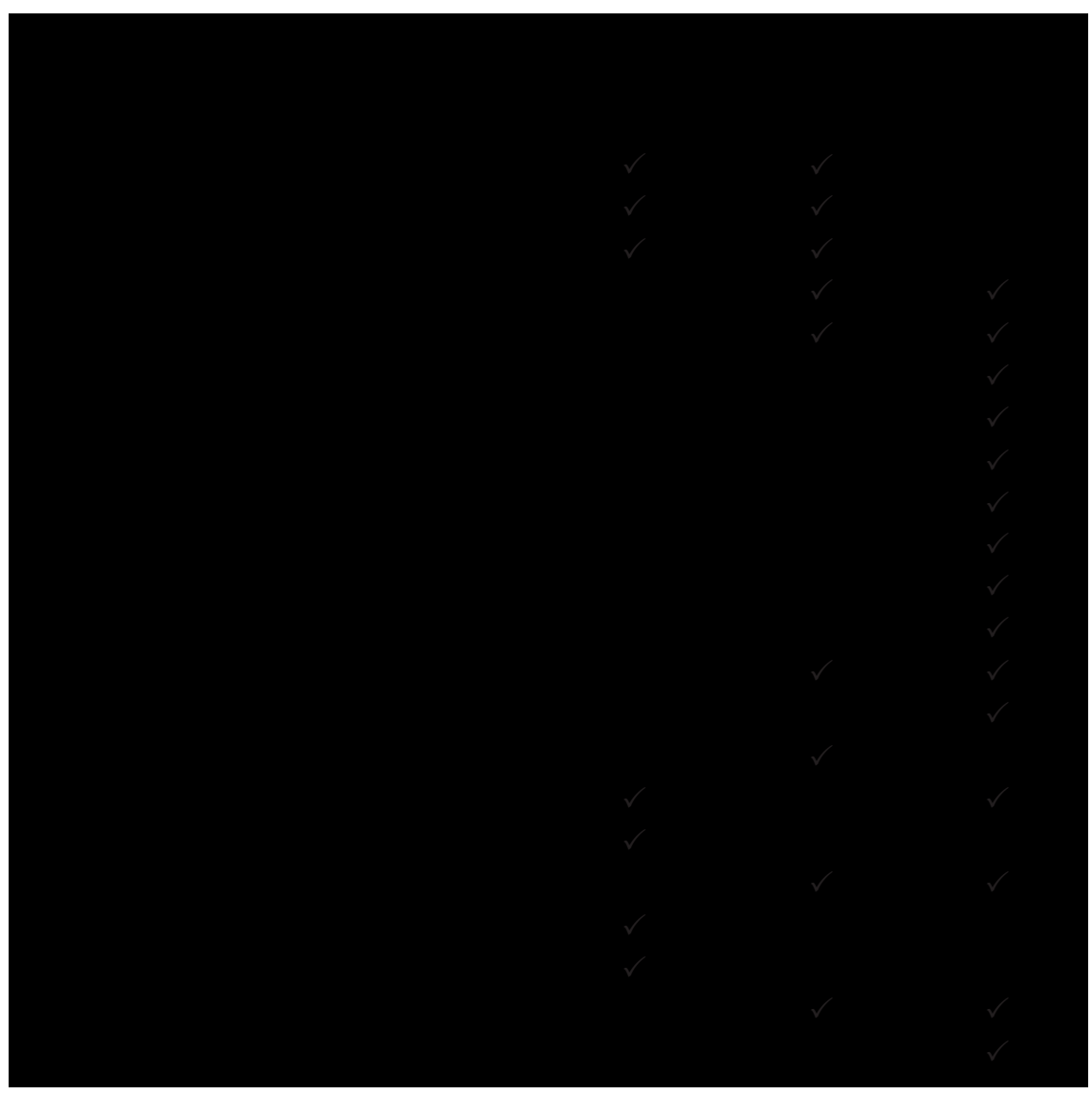

superkoiling DNA. Banyak antibiotik bekerja dengan menyerang gyrase. Gyrase DNA bakteri hadir di prokariota dan beberapa eukariota, tetapi enzim ini tidak sepenuhnya mirip dalam struktur atau urutan, dan memiliki kedekatan yang berbeda untuk setiap molekul yang berbeda. Enzim ini tidak ditemukan pada manusia. Hal ini membuat gyrase sebagai target yang baik untuk antibiotik. Bakteri patogen memiliki struktur gen $G y r-B$ yang spesifik dibandingkan bakteri lainnya (Thaithongnum et al., 2006).

\section{Hasil Sekuensing Gen-Gen Spesifik Vibrio Berpendar}

Hasil sekuensing gen haemolysin dari bakteri hasil koleksi menunjukkan kemiripan $94 \%$ dengan gen haemolysin bakteri $V$. harveyi yang terdeposit pada NCBI (Gambar 1).
Sedangkan hasil sekuensing gen gyrase memiliki kemiripan 99\% dengan gen gyrase bakteri $V$. harveyi (Gambar 3). Kemiripan gen target yang diisolasi dibandingkan dengan beberapa sekuen referensi menentukan berhasil tidaknya isolasi gen spesifik. Jumlah sekuen referensi yang diperlukan tergantung dari sampel target. Semakin banyak referensi sekuen gen yang kita peroleh akan lebih baik agar kita dapat mendesain primer di daerah yang benar-benar sama (conserved region) setelah sekuen tersebut disejajarkan (alignment). Pada dasarnya satu data sekuen sudah dapat dijadikan referensi dengan syarat bahwa sampel target nantinya memiliki kesamaan spesies atau dengan kata lain secara genetik sangat mirip. Hasil sekuensing selanjutnya digunakan untuk mendesain primer spesifik bakteri Vibrio patogen. 
Sekuen gen haemolysin

>1st_BASE_399953_1hem_VhF1

GTAGTGCTATACTACATTAATCTTGCTCCGCAGCCGACTCATCAGAGCCTTCTTACCTG CTAAATGCСTCAGAAGTGAGAAGCGCACAACAAAAGCAAACATACACCTACGTACGATG CTGGTATCGAACTAGTTATTCACATGATGACCCAGAAACCGACTGGGAGTGGGCAGAA AATCCAGATGGCAGTTATTTCACTATCGAAGGCTATTGGTGGAACGCACTCTCGTTTAA AAACATGTTCTATACCAATACACCGCAAAGTGTTATCAAGCAAAANCCCATTNAG

\section{BLAST}

\section{Basic Local Alignment Search Tool}

NCBI/ BLAST/ blastn suite/ Formatting Results - VM5G11FZ016

Nucleotide Sequence (226 letters)

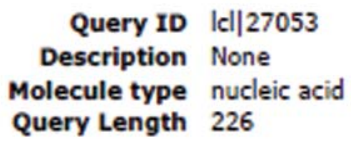

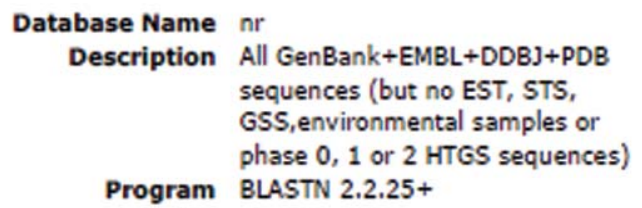

Database Name nr

Description All GenBank+EMBL+DDBJ+PDB sequences (but no EST, STS, GSS,environmental samples or phase 0,1 or 2 HTGS sequences)

Program BLASTN 2.2.25+

\section{Descriptions}

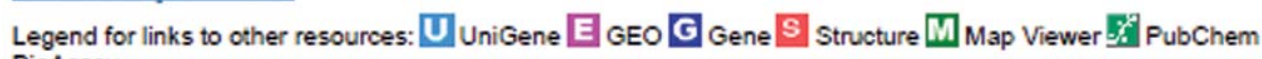
BioAssay

\begin{tabular}{|c|c|c|c|c|c|c|}
\hline \multicolumn{2}{|c|}{ Accession Description } & $\frac{\text { Max }}{\underline{\text { score }}}$ & $\underline{\text { Total }}$ & $\begin{array}{l}\text { Query } \\
\text { coverage } \\
\end{array}$ & $\begin{array}{l}\underline{\mathrm{E}} \\
\text { value } \\
\end{array}$ & $\underline{\text { Max }}$ \\
\hline EU827170.1 & $\begin{array}{l}\text { Vibrio harveyi strain VH34 } \\
\text { hemolysin gene, complete cods }\end{array}$ & $\underline{346}$ & 346 & $100 \%$ & $4 e-92$ & $94 \%$ \\
\hline AB271112.1 & $\begin{array}{l}\text { Vibrio campbelli vcamhly gene for } \\
\text { hemolysin, complete ods, strain: } 53\end{array}$ & 340 & 340 & $100 \%$ & $2 e-90$ & $93 \%$ \\
\hline$\underline{\text { AB271111.1 }}$ & $\begin{array}{l}\text { Vibrio campbellii vcamhly gene for } \\
\text { hemolysin, complete cos, strain: } 53\end{array}$ & $\underline{340}$ & 340 & $100 \%$ & $2 \mathrm{e}-90$ & $93 \%$ \\
\hline AB2711101 & $\begin{array}{l}\text { Vibrio campbelli vcamhly gene for } \\
\text { hemolysin, complete ods, strain: } 52\end{array}$ & 340 & 340 & $100 \%$ & $2 e-90$ & $83 \%$ \\
\hline$\underline{A B 271109.1}$ & $\begin{array}{l}\text { Vibrio campbellii vcamhly gene for } \\
\text { hemolysin, complete ods, strain: } 41\end{array}$ & $\underline{340}$ & 340 & $100 \%$ & $2 e-90$ & $93 \%$ \\
\hline DQ434995.1 & $\begin{array}{l}\text { Vibrio campbellii CAIM } 519 T \\
\text { hemolysin gene (vch), complete cds }\end{array}$ & 335 & 335 & $100 \%$ & $8 e-89$ & $93 \%$ \\
\hline $\mathrm{DQ} 356218.1$ & $\begin{array}{l}\text { Vibrio campbelli strain NBRC } \\
15631 \text { hemolysin (vch) gene. } \\
\text { complete cods }\end{array}$ & 335 & 335 & $100 \%$ & $8 e-89$ & $23 \%$ \\
\hline$\underline{\text { CP000790.1 }}$ & $\begin{array}{l}\text { Vibrio harveyi ATCC BAA-1116 } \\
\text { chromosome II, complete sequence }\end{array}$ & $\underline{329}$ & 329 & $100 \%$ & $4 e-87$ & $92 \%$ \\
\hline DQ434996.1 & $\begin{array}{l}\text { Vibrio campbellii hemolysin gene } \\
\text { (vch), compete cods }\end{array}$ & 322 & 328 & $100 \%$ & $4 e-87$ & $92 \%$ \\
\hline DQ663484.1 & $\begin{array}{l}\text { Vibrio campbellii strain VIB } 285 \\
\text { VHHITLH hemolysin gene, partial } \\
\text { coss }\end{array}$ & $\underline{237}$ & 237 & $71 \%$ & $2 \mathrm{e}-59$ & $93 \%$ \\
\hline
\end{tabular}

Gambar 1. Hasil sekuensing dan alignment gen haemolysin

Figure 1. Result of sequencing and alignment of haemolysin gene 


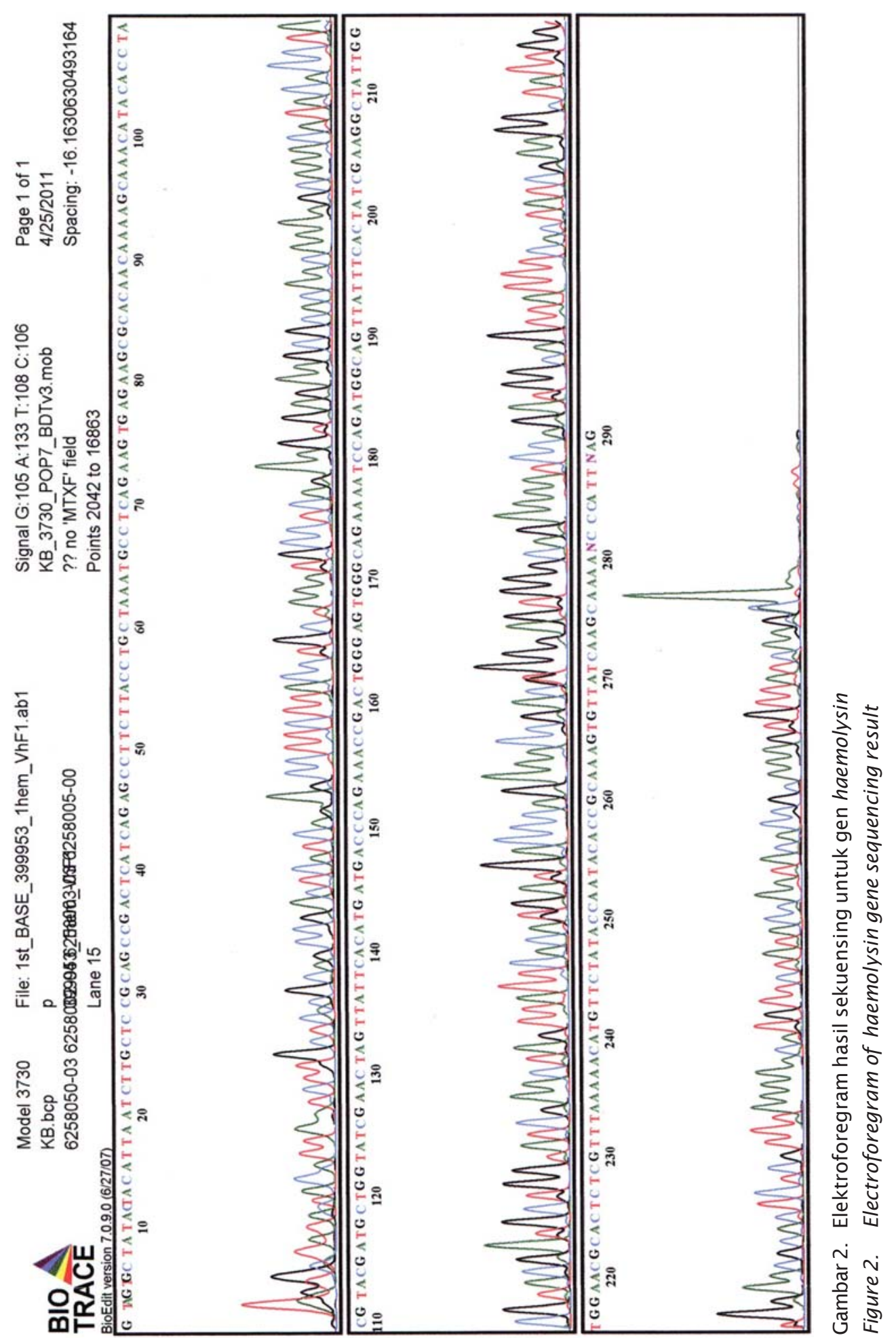




\title{
Sekuen gen gyrase
}

>1st_BASE_399959_120_gyr_A2

\begin{abstract}
NGGCCTTATAGCAAACTTACCATCACGGTGAGCCTCAAGCGCCACTAGCAGTAATTGGT GATACTGACCAAACGGGTACACAGATCCGCTTCTGGCCAAGCGCTGAAACCTTCACAA ATATCGAATTCCATTACGATATCCTAGCAAAACGTCTACGTGAGCTTTCTTTCCTAAACT CAGGTGTTTCTATCAAGCTGGTTGATGAGCGTGAAGCAGACAAGAGTGACCACTTCATG TTTGAAGGTGGTATTCAAGCGTTCGTTGAGCACCTAAACACCAACAAAACACCGATCAT TGAGAAAATCTTCCACTTCTATTTTGAACGTGAAGATGGCATTGCTATAAAATA
\end{abstract}

\begin{tabular}{|c|c|c|c|c|c|c|c|}
\hline \multicolumn{8}{|c|}{ Sequences producing significant alignments: } \\
\hline Accession & Description & Max score & $\frac{\text { Total }}{\text { score }}$ & $\begin{array}{l}\text { Query } \\
\text { coverage }\end{array}$ & Evalue & $\frac{\text { Max }}{\text { ident }}$ & Links \\
\hline AY988161.1 & $\begin{array}{l}\text { Vibrio sp. PIZ } 9806 \text { DNA } \\
\text { gyrase subunit B (gyrB) gene, } \\
\text { partial cds }\end{array}$ & $\underline{606}$ & 606 & $95 \%$ & $3.00 E-170$ & $99 \%$ & \\
\hline AB609127.1 & $\begin{array}{l}\text { Vibrio owensii gyrB gene for } \\
\text { DNA gyrase B subunit, partial } \\
\text { cds }\end{array}$ & $\underline{601}$ & 601 & $95 \%$ & $1.00 E-168$ & $99 \%$ & \\
\hline GU078683.1 & $\begin{array}{l}\text { Vibrio communis strain R- } \\
40504 \text { DNA gyrase B subunit } \\
\text { (gyrB) gene, partial cols }\end{array}$ & $\underline{601}$ & 601 & $95 \%$ & 1.00E-168 & $99 \%$ & \\
\hline FM202605.1 & $\begin{array}{l}\text { Vibrio campbellii partial gyrB } \\
\text { gene for gyrase B subunit, } \\
\text { strain R1311 }\end{array}$ & $\underline{601}$ & 601 & $95 \%$ & $1.00 E-168$ & $99 \%$ & \\
\hline FM202604.1 & $\begin{array}{l}\text { Vibrio campbellii partial gyrB } \\
\text { gene for gyrase B subunit, } \\
\text { strain R1117 }\end{array}$ & $\underline{601}$ & 601 & $95 \%$ & $1.00 E-168$ & $99 \%$ & \\
\hline FM202597.1 & $\begin{array}{l}\text { Vibrio campbellii partial gyrB } \\
\text { gene for gyrase B subunit, } \\
\text { culture collection CAIM } 392\end{array}$ & $\underline{601}$ & 601 & $95 \%$ & $1.00 E-168$ & $99 \%$ & \\
\hline EU672845.1 & $\begin{array}{l}\text { Vibrio harveyi strain ATCC } \\
33842 \text { DNA gyrase subunit B } \\
\text { (gyrB) gene, partial cds }\end{array}$ & $\underline{601}$ & 601 & $95 \%$ & 1.00E-168 & $99 \%$ & \\
\hline EF596586.1 & $\begin{array}{l}\text { CAIM1283 DNA gyrase B } \\
\text { subunit (gyrB) gene, partial } \\
\text { cds }\end{array}$ & $\underline{601}$ & 601 & $95 \%$ & $1.00 E-168$ & $99 \%$ & \\
\hline EF596585.1 & $\begin{array}{l}\text { Vibrio campbellii strain } \\
\text { CAIM1500 DNA gyrase B } \\
\text { subunit (gyrB) gene, partial } \\
\text { cds }\end{array}$ & $\underline{601}$ & 601 & $95 \%$ & $1.00 E-168$ & $99 \%$ & \\
\hline EF596583.1 & $\begin{array}{l}\text { Vibrio campbellii strain } \\
\text { CAIM392 DNA gyrase B } \\
\text { subunit (gyrB) gene, partial } \\
\text { cds }\end{array}$ & $\underline{601}$ & 601 & $95 \%$ & 1.00E-168 & $99 \%$ & \\
\hline EF596576.1 & $\begin{array}{l}\text { Vibrio campbellii strain } \\
\text { CAIM3 DNA gyrase B subunit } \\
\text { (gyrB) gene, partial cds }\end{array}$ & $\underline{601}$ & 601 & $95 \%$ & 1.00E-168 & $99 \%$ & \\
\hline DQ345719.1 & $\begin{array}{l}\text { Vibrio harveyi strain Thai } \\
\text { DNA gyrase subunit b (gyrB) } \\
\text { gene, partial cds }\end{array}$ & 601 & 601 & $95 \%$ & 1.00E-168 & $99 \%$ & \\
\hline
\end{tabular}

Gambar 3. Hasil sekuensing dan alignment gen gyrase

Figure 3. Gyrase gene sequencing and alignment result 


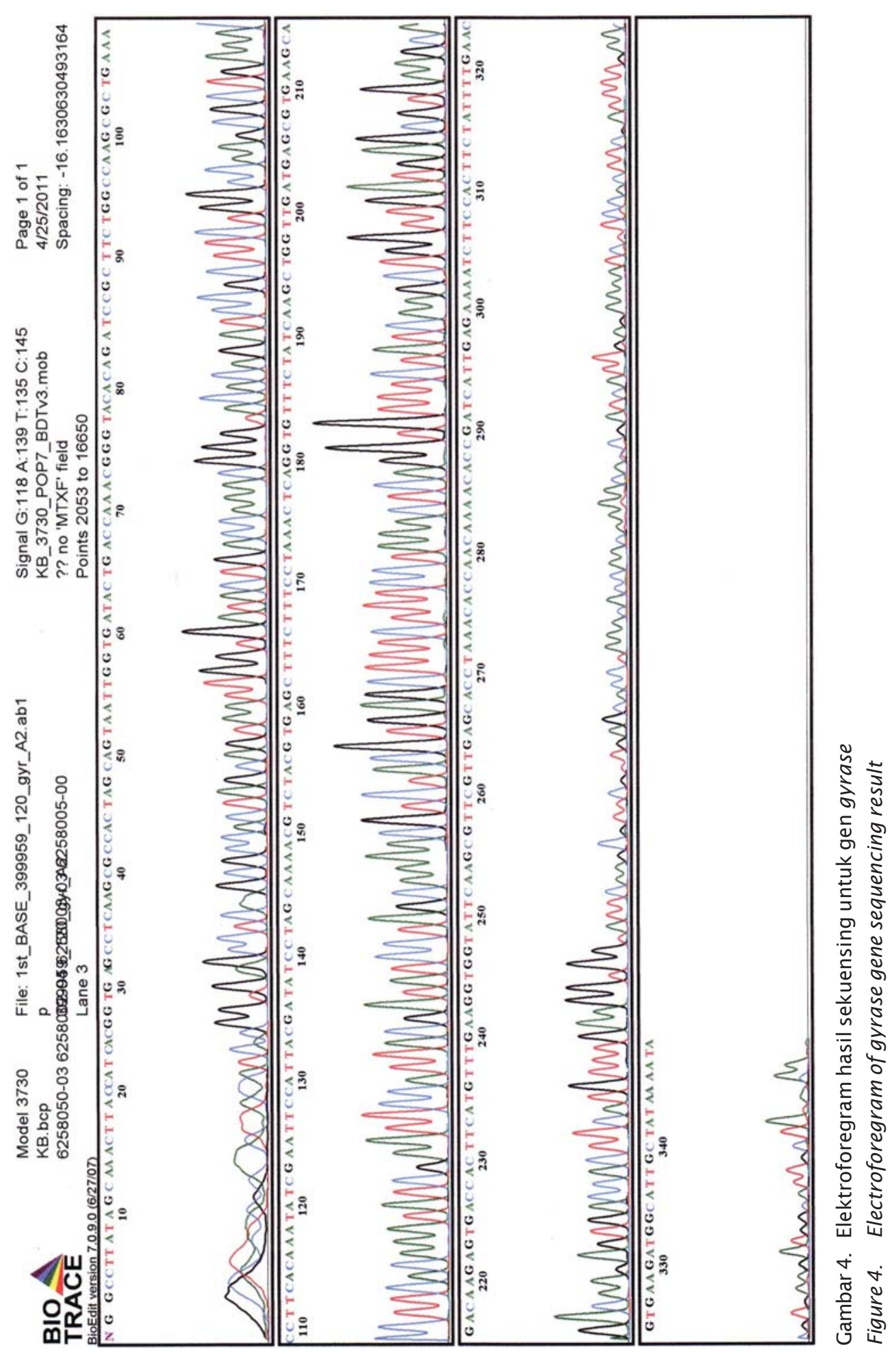




\section{Desain Primer Spesifik}

Desain primer spesifik dilakukan dengan bantuan perangkat lunak Primer3Plus dengan menggunakan hasil sekuen gen spesifik haemolysin dan gyrase (Gambar 5). Pensejajaran secara manual dilakukan untuk membandingkan sekuen gen dari bakteri hasil koleksi dengan sekuen gen sejenis yang terdeposit pada NCBI (Gambar 6). Pada dasarnya sembarang daerah tertentu pada sekuen referensi dapat diambil untuk dijadikan primer, tanpa perlu bantuan software khusus. Namun cara ini amat berisiko karena kita tidak mengetahui bagaimana kualitas primer yang dihasilkan nantinya.
Hasil desain diperoleh tiga pasang primer untuk deteksi gen haemolysin dan dua pasang primer untuk gen gyrase (Tabel 3). Pada setiap hasil desain primer yang dikeluarkan oleh perangkat lunak Primer3 selalu terdapat pasangan primer forward dan reverse yang direkomendasikan serta pilihan pasangan primer lain sebagai cadangan.

\section{UCAPAN TERIMA KASIH}

Penelitian ini bagian dari riset Manajemen Kesehatan Ikan dan Lingkungan Balai Penelitian dan Pengembangan Budidaya Air Payau dan dibiayai oleh APBN Kementerian Kelautan dan Perikanan tahun anggaran 2010-2011.

\section{Primer3Plus}

pick primers from a DNA sequence

\section{Primer3Manager Help}

About

Source Code

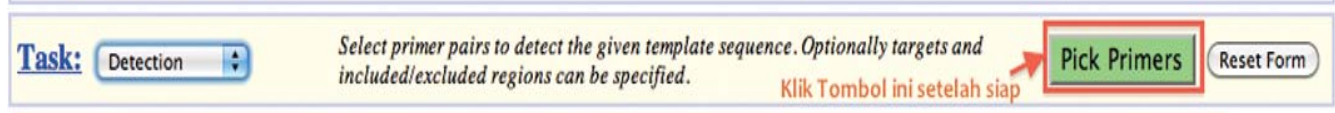

\begin{tabular}{|c|c|c|c|c|c|}
\hline Main & General Settings & Advanced Settings & Internal Oligo & Penalty Weights & Sequence Quality \\
\hline Sequence Id: & & \multicolumn{4}{|c|}{ Option Tambahan } \\
\hline \multicolumn{2}{|c|}{ Paste source sequence below } & Or upload sequence file: & Choose File nof & selected & Upload File \\
\hline \multicolumn{6}{|c|}{ 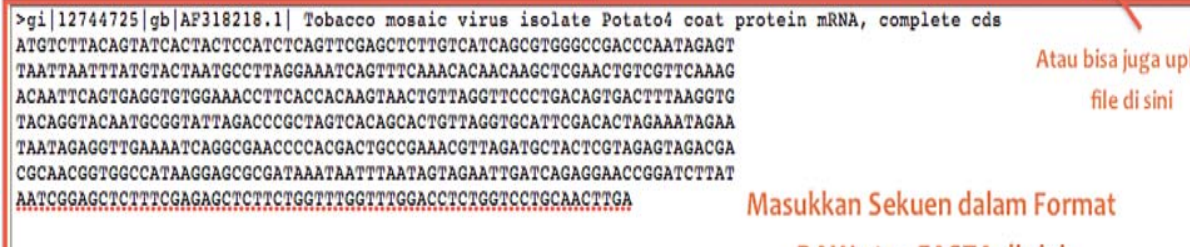 } \\
\hline
\end{tabular}

Mark selected region: $\leftrightarrow$ (II) (11) Clear Save Sequence

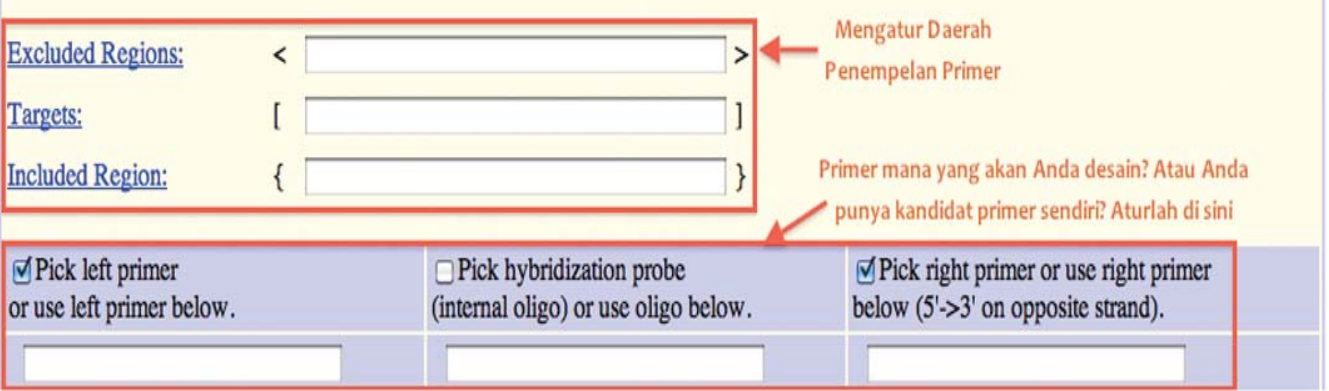

Gambar 5. Proses desain primer menggunakan perangkat lunak Primer3Plus

Figure 5. Primer design process using software Primer3Plus 


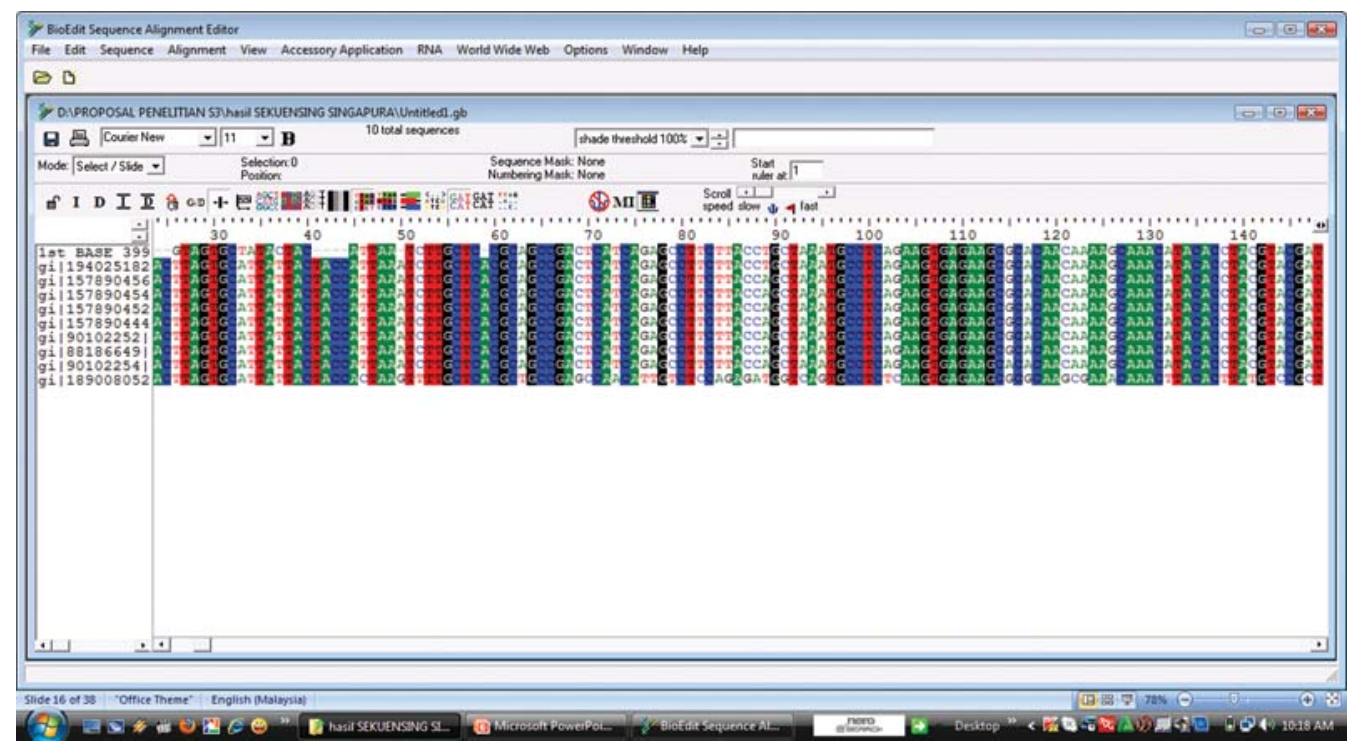

Gambar 6. Proses pensejajaran hasil sekuen secara manual menggunakan perangkat lunak Bioedit Figure 6. The process sequence alignment results manually using software Bioedit

Tabel 3. Hasil desain primer spesifik

Table 3. The result of specific primer design

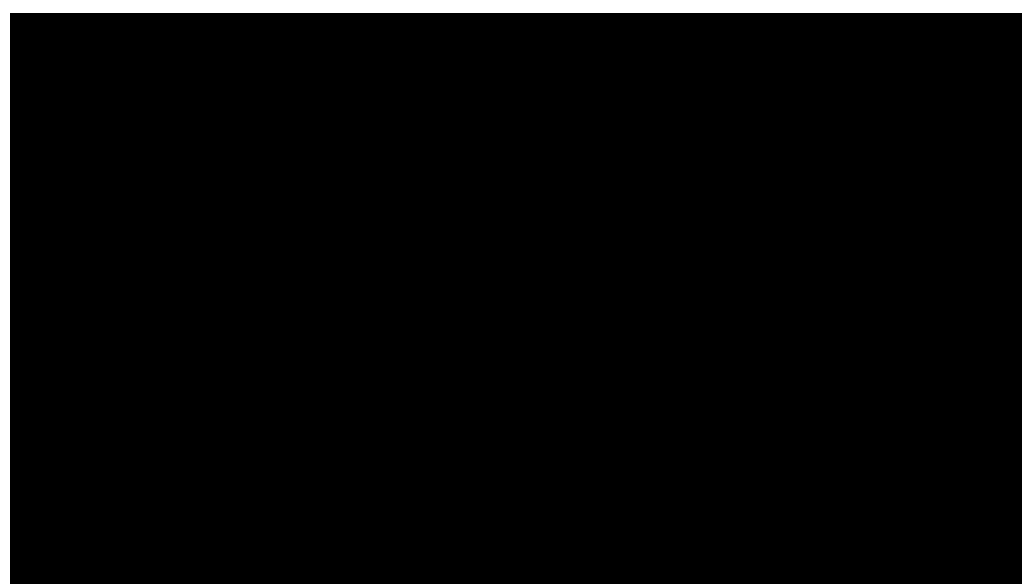

\section{DAFTAR ACUAN}

Austin, B. \& Zhang, X.-H. 2006. Vibrio harveyi: a significant pathogen of marine vertebrates and invertebrates. Lett. Appl. Microbiol., 43: 119-124.

Baticados, M.C.L., Lavilla-Pitogo, C.R., CruzLacierda, E.R., de la Pena, L.D., \& Sunaz, N.A. 1990. Studies on the chemical control of luminous bacteria Vibrio harveyi and $V$. splendidus isolated from diseased Penaeus monodon larvae and rearing water. Diseases of Aquatic Organism., 9: 133 139.

Bej, A.K., Patterson, D.P., Brasher, C.W., Vickery, M.C., Jones, D.D., \& Kaysner, C.A. 1999. Detection of total and haemolysin-producing Vibrio parahaemolyticus in shellfish using multiplex PCR amplification of $t l, t d h$ and trh. J. Microbiol. Methods, 36: 21 5-225. 
Ben_Haim, Y., Thompson, F. L., Thompson, C. C., Cnockaert, M.C., Hoste, B., Swings, J., \& Rosenberg, E. 2003. Vibrio coralliilyticus sp. nov., a temperature-dependent pathogen of the coral Pocillopora damicornis. Int. J. Syst. Evol. Microbiol., 53: 309-315.

Benson, H.J. 1985. Microbiological Applications: A. Laboratory Manual in General Microbiology. Fourth Edition. Wm. C. Brown Publishers. Dubuque, lowa, 450 pp.

Cano-Gomez, A., Bourne, D.G., Hall, M.R., Owens, L. \& Hoj, L. 2009. Molecular identification, typing and tracking of Vibrio harveyi in aquaculture systems: Current methods and future prospects. Aquaculture, 287: 1-10.

Conejero, M.J.U. \& Hedreyda, C.T. 2004. PCR detection of haemolysin (vhh) gene in Vibrio harveyi. J. Gen. Appl. Microbiol., 50: 137-142.

Cunningham, C.O. 2002. Molecular diagnosis of fish and shellfish diseases: present status and potential use in disease control. Aquaculture, 206: 19-55.

Defoirdt, T. 2007. Quorum sensing disruption and the use of short-chain fatty acids and polyhydroxyalkanoates to control luminescent Vibriosis. PhD thesis, Ghent University, Belgium, $228 \mathrm{pp}$.

Karunasagar, I., Pai, R., Malathi, G.R., \& Karunasagar, I. 1994. Mass mortality of Penaeus monodon larvae due to antibioticresistant Vibrio harveyi infection. Aquaculture, 128: 203-209.

Moriarty, D.J.W. 1998. Control of luminous Vibrio species in penaeid aquaculture ponds. Aquaculture, 168: 351-358.

Nishibuchi, M., Khaeomanee-iam, V., Honda, T., Kaper, J.B., \& Miwatani, T. 1990. Compara- tive analysis of the haemolysin genes of Vibrio cholerae non-O1, Vibrio mimicus, and Vibrio hollisae that are similar to the $t d h$ gene of Vibrio parahaemolyticus. FEMS Microbiol. Lett., 67: 251-256.

Nishibuchi, M. \& Kaper, J. 1995. Thermostable direct haemolysin gene of Vibrio parahaemolyticus: A virulence gene acquired by a marine bacterium. Infect. Immun., 63: 2,093-2,099.

Pang, L., Zhang, X.H., Zhong, Y., Chen, J., Li, Y., \& Austin, B. 2006. Identification of Vibrio harveyi using PCR amplification of the toxR gene. Lett. Appl. Microbiol., 43: 249-255.

Parenrengi, A. 2000. Studies on genetic variability of groupers (Genus: Epinephelus) from Indo-Malaysian waters using PCRRAPD Analysis. Thesis master of Science, Kolej University Terengganu, Universiti Putra Malaysia, 174 pp.

Saulnier, D., Haffner, P., Goarant, C., Levy, P., \& Ansquer, D. 2000. Experimental infection models for shrimp Vibriosis studies: a review. Aquaculture, 191: 133-144.

Thaithongnum, S., Ratanama, R., Weeradechapol, K., Sukhoom, A., \& Vuddhakul, V. 2006. Detection of Vibrio harveyi in shrimp postlavae and hatchery tank water by the most probable number technique with PCR. Aquaculture, 261: 1-9.

Zhang, X.H. \& Austin, B. 2000. Pathogenicity of Vibrio harveyi to salmonids. J. Fish Dis., 23: 93-102.

Zhang, X.H., Meaden, P.G., \& Austin, B. 2001. Duplication of haemolysin genes in a virulent isolate of Vibrio harveyi. Appl. Environ. Microbiol., 67: 3,161-3,167. 